\title{
OSTEOARTICULAR INFECTIONS IN PEDIATRICS: EPIDEMIOLOGICAL UPDATE
}

BACKGROUND AND AIMS Bone and joint infections (BJI) are usually secondary to haematogenic dissemination and affect mainly children younger than 5 years old. Early diagnosis and treatment can reduce the risk of complications and sequelae. The objective was to evaluate the clinical and laboratory characteristics (Table 1), bacterial identification rate, etiology and microbial susceptibility profile of BJI that occurred at Santa Casa de Sao Paulo, Brazil.

METHODS - We've accessed medical records from children under 16 years old with BJI, admitted at our hospital between January 2002 and December 2016.
RESULTS - We've included 64 children. An agent was identified in $62 \%$ of the cases: in blood culture $(31 \%)$, joint secretion $(10 \%)$, peripheral blood culture plus joint secretion or bone fragment (20\%). The main etiologic agent was S. aureus (40\%), followed by S. pyogenes (8\%). In the susceptibility profile, $73 \%$ of the $S$. aureus were methicillin-sensitive (MSSA) and 27\% were resistant (MRSA). All MRSA, except one, was considered community associated (CA-MRSA) by phenotypic profile. All patients were treated with endovenous antibiotic.

Table 1 - Clinical and laboratorial features of bone and joint infections patients

\begin{tabular}{|c|c|c|c|}
\hline & OSTEOARTHRITIS & OSTEOMYELITIS & $\begin{array}{l}\text { OSTEOARTHRITIS } \\
+ \text { OSTEOMYELITIS }\end{array}$ \\
\hline Number of patients & 29 & 27 & 8 \\
\hline $\begin{array}{l}\text { Age in months } \\
\text { (avarage) }\end{array}$ & 67,7 & 81,3 & 101 \\
\hline $\begin{array}{c}\text { Hospitalization days } \\
\text { (avarage) }\end{array}$ & 14,4 & 22,8 & 25,2 \\
\hline Fever days (avarage) & 5 & 13,3 & 6 \\
\hline $\begin{array}{l}\text { ESR in diagnosis } \\
\text { (avarage--mm/h) }\end{array}$ & 65,7 & 65,7 & 67,3 \\
\hline $\begin{array}{l}\text { CRP in diagnosis } \\
\text { (avarage }-\mathrm{mg} / \mathrm{dL} \text { ) }\end{array}$ & 8,1 & 8,1 & 9,8 \\
\hline $\begin{array}{c}\text { Leukocytosis in } \\
\text { diagnosis (average - } \\
\mathrm{mm}^{3} \text { ) }\end{array}$ & 12620 & 14580 & 12030 \\
\hline $\begin{array}{l}\text { Days of antibiotic } \\
\text { duration (average) }\end{array}$ & 17,2 & 29 & 41,8 \\
\hline
\end{tabular}

CONCLUSION - We could identify a high rate of agents (62\%), with the highest positivity observed in patients who had osteomyelitis. The rate of MRSA raises the question whether oxacillin should still be maintained as the first choice as empirical therapy for OAl. Kingella kingae, considered one of the most frequent agent in pediatric group, was not observed in our cases; possibly because we do not routinely use identification methods for this agent. All patients were hospitalized and treated with intravenous antibiotics. Socioeconomic-cultural conditions of our population can explain the longer hospitalization periods and antibiotic use. 